\title{
Analysis of Factors Which Affect Budgetary Slack (Survey of SOE in Bandung)
}

\author{
Melania Lintang Kenisah, Yenni Carolina, Rapina \\ Maranatha Christian University \\ melania.lintangkenisah@gmail.com
}

\begin{abstract}
This study aims to analyze the factors that affect budgetary slack which include employee motivation and asymmetric information with participative budgeting as the antecedent variables. The research method was conducted through a survey method by distributing questionnaires to 229 heads of responsibility center on SOEs in Bandung. In addition, interviews and group discussions were conducted to improve data collection. The data obtained were analyzed using the structural equation model - LISREL. The results showed that asymmetric information has a positive effect on budgetary slack and employee motivation has a negative effect on budgetary slack. Meanwhile, participative budgeting has a positive effect on asymmetric information and employee motivation.

Keywords: Participative Budgeting, Asymmetric Information, Employee Motivation, Budgetary Slack
\end{abstract}

JEL $\quad:$ G31

DOI : 10.24002/kinerja.v22i2.2415

Received : 08/13/2019 Reviewed: 01/29/2020 Final Version: 02/20/2020 


\section{INTRODUCTION}

Budget has an important role in an organization. This role is reflected at the function of the budget which is as a planning and control tool for a company (Anthony \& Govindarajan, 2007). Thus, the budget estimates planning process is a determinant of organizational success. Another important function of budget is to assess the performance of business units or individuals. Therefore, budget has a significant effect towards employee behavior (Weygandt et al., 2015). In order to obtain a good performance appraisal, employees strive to create "breathing space" in budgeting by increasing the estimates of cost and reducing the estimates of income excessively (Horngren et al., 2015; Walther \& Skousen, 2009). In addition, the "tradition" of cutting budgets at the time of proposing a budget often raises employee initiatives to overstate the budget (Samad, 2018, as a Chairman of Corruption Eradication Commission (CEC) for the period 2011-2015). Behavior of overstating the budget is known / termed as budgetary slack, which is an unethical behavior and leads to dysfunctional behavior (Goebel \& WeiBenberger, 2016; Adnan \& Ali, 2014).

Problems which are related to budget dysfunctional behavior occur in various companies, especially at SOEs. The investigations conducted by the Indonesian Corruption Watch (ICW) found that corruption that had been occurring in Indonesia until 2017 was indicated through budgetary slacks (77 cases) (Alamsyah, 2018, as a staff of the ICW Investigation Division). Novo (2017) as the Expert Staff of the Minister of SOE added that corruption occurs most frequently when the project is run by marking up the budget. Parmoredjo (2018) as the Accounting Assessment Officer of PT Telekomunikasi Indonesia stated that the existence of a policy for budget cuts indicated the initiative of cost center managers to conduct budgetary slack. The Head of the Attorney General's Legal Information Center, Rum (2017), stated that a similar problem also occurred at PT Pertamina Patra Niaga in which the budget submission by the company was allegedly marked up. A similar case was expressed by Pangarso (2018), as the Deputy Chairman of Commission VI of the Indonesian House of Representatives. He expressed his suspicion to PT Waskita Karya, which had not been transparent so far and was alleged to manipulate its budget. Syarif (2018), the Deputy Chairman of CEC, also had the same concern on PT Nindya Karya Persero that was suspected of conducting deviations and marking up the budget of the Sabang jetty construction project.

Budgetary slack was affected by many factors. One of them is asymmetric information (Merchant \& Van der Stede, 2012). Asymmetric information occurs when subordinates hide the information so that superiors do not have sufficient information to measure the actual contributions made by subordinates (Anthony \& Govindarajan, 2007). One way that can be done to reduce asymmetric information is through participative budgeting (Drury, 2018). Kren \& Maiga (2015) stated that participative budgeting can reduce the level of asymmetric information. However, there are several studies that showed contradictory results, namely Basuki (2015), Cheng et al. (2014), Lavarda \& Almeida (2013), and Douglas \& Wier (2000) who 
stated that companies with participative budgeting cannot minimize the occurrence of asymmetric information.

Another factor affecting the budgetary slack is the employee motivation (Baerdemaeker \& Bruggeman, 2015). The form of employee motivation is internal strength from each of the employees. If the internal strength is developed, it is possible for employees to pursue activities which are considered meaningful and interesting (Colquit et al., 2017). Activities that are considered meaningful and interesting are activities that are perceived as positive, which can reduce the potential for budgetary slack. One way to increase employee motivation is to invite them to participate in determining the budget estimating plan (Noreen et al., 2014). This is emphasized through the results of the research conducted by Dow et al. (2015), Yee et al. (2016), and Djalil et al. (2017), who stated that participative budgeting affects employee motivation.

The purpose of this study is to analyze the factors that affect budgetary slack, consisting of employee motivation and asymmetric information with participative budgeting as the antecedent variables. This study presents the asymmetric information and employee motivation (focusing on intrinsic motivation) as the variables that together mediate the relationship between participative budgeting and budgetary slack. This is what differentiates this study from the previous studies. This study is expected to provide input in the form of policies for the government, especially for the Ministry of SOE in improving the governance and performance of SOE companies in terms of budgeting.

\section{LITERATURE REVIEW}

\subsection{Budgetary Slack}

Theoretically, budgetary slack has been defined by many experts and researchers. Budgetary slack is considered as a "cushion" for managers or participants involved in the budget planning process. Budgetary slack occurs when the estimated amount of the income budget is too low and the cost budget is too high from their best estimates in the future (Ngo et al., 2017; Weygandt et al., 2015; Faria \& Silva, 2013). Furthermore, budgetary slack is designed to create a "breathing room" for budget planners (Walther \& Skousen, 2009). Then, budgetary slack is also defined as a budget that will facilitate the achievement of targets (Anthony \& Govindarajan, 2007).

Based on the studies done by researchers, the majority of research about budgetary slack uses many indicators from research conducted by Onsi (1973), Dunk (1993), and Van der Stede (2000). Yet, this study uses the indicators developed by Van der Stede (2000). This is because these indicators are the result of refinement of indicators developed by Onsi (1973) and Dunk (1993). In addition, the Van der Stede (2000) is an indicator that is in line with some of the demands of budgeting policies that occur in SOEs. One of them is listed in the "Company 
Regulations of the Company (Persero) PT Telekomunikasi Indonesia, Tbk. PD.306.000 / r.01 / HK.230 / COP-A0010000 / 2013".

\subsection{Asymmetric Information}

Asymmetric information can be stated as a concept that occurs. It is also the most basic in theory involving two parties, namely superiors and subordinates (Macintosh \& Quattrone, 2010). According to the agency theory, managers will use asymmetric information opportunistically so that it has an overall impact on information.

Merchant \& Van der Stede (2012) stated that asymmetrical information occurs when superiors have an incomplete knowledge about what could be achieved in certain areas. According to Chandra (2011), this condition occurs when the principal (manager) has insufficient information about the activities of the agent (subordinate), the principal cannot ensure the contribution given by an agent for the company's results. Asymmetric information occurs when an agent (subordinate) conceals information so that the principal (supervisor) does not have sufficient information to measure the actual contribution made by the agent (subordinate) for the company.

Asymmetric information can be measured by using several indicators. In fact, the major studies related to asymmetric information had used indicators which were developed by Jaworski \& Young (1992) and Dunk (1993) in their measurements. In this study, the indicators used are indicators developed by Dunk (1993). This is because this indicator is the one which is frequently used to measure asymmetric information.

\subsection{Employee Motivation}

Motivation is defined as a set of energetic forces that originate from within and from outside of employees, work-related business initiatives, and determine the direction, strength, and perseverance (Colquitt et al., 2017). Motivation is related to a series of processes that arouse, direct, and maintain behavior towards a goal (Greenberg, 2011). Furthermore, Newstrom (2015) explains that the working motivation is the result of a series of internal and external forces that cause employees to choose the right actions and engage in certain behaviors.

In this study, employee motivation will be focused on intrinsic motivation or motivation that comes from within the employee. Intrinsic motivation in the theory of "self-determination" is known as autonomous motivation (Weibel et al., 2014), while extrinsic motivation is known as controlled motivation (Fall \& Roussel, 2014: 208). Baerdermaeker and Bruggeman (2015) conducted a study which was related to these two motivations that were associated with budgetary slack. The results of this study indicate that autonomous motivation is more capable to reduce the potential for budgetary slack compared to the use of controlled motivation. This is the basis for researchers to focus this research on the direction of intrinsic motivation. 
Intrinsic motivation here refers to motivation control by individuals and based on experience from the activity itself (McShane \& Glinow, 2018). Things that intrinsically motivate is the internal appreciation that a person feels when he/ she is working, so there is a close and direct relationship between work and appreciation. An employee in this situation is motivated by himself (Newstrom, 2015).

Measurement of intrinsic motivation could be done using several indicators. Based on previous studies, there were two studies that developed indicators of measurement of intrinsic motivation conducted by Dermer (1975) and Warr et al. (1979). In this study, the indicators used are indicators developed by Warr et al. (1979). This is because these indicators are the result of refinement of indicators compiled by Dermer (1975) and many researchers have used these indicators to measure intrinsic motivation. This indicator according to Warr et al. (1979) has also been modified and linked to the budget by Dow et al. (2015).

\subsection{Participative Budgeting}

Participative budgeting is a bottom-up approach for budgeting. Furthermore, Shim et al. (2012) explained that participative budgeting is a budgeting system that involves all employees in the process of preparing the organization's budget. Top management can start the budget process with general budgetary guidelines, but it is the lower-level units that encourage budget development in their units (Walther \& Skousen, 2009). Hansen et al. (2009) added that participative budgeting communicates a sense of responsibility and fosters creativity for lower-level managers.

Based on previous studies, participative budgeting can be measured by several indicators and the majority is using the indicators developed by Milani (1975), Merchant (1981), and Barki and Hartwick (1994). The participative budgeting indicator used is an indicator developed by Milani (1975).

\section{HYPOTHESIS DEVELOPMENT}

\subsection{Asymmetric Information and Budgetary Slack}

Budgetary slack is about the difference between the projected income and costs provided by managers with realistic estimates that are actually able to be achieved (Shim et al., 2012). A budgetary slack occurs when the budget revenue target is made lower than the actual potential revenue (Kridawan \& Mahmud, 2014). Slack can occur if there is asymmetric information (Dunk \& Nouri, 1998). The higher the level of asymmetric information refers to the higher the chance of conducting budgetary slack (Fanani \& Saudale, 2018). Asymmetric information can be interpreted as concepts that occur in the agency theory. Asymmetric information occurs when an agent (subordinate) conceals the information so that the principal (supervisor) does not have any sufficient information to measure the actual contribution made by the agent (subordinate) to the company (Macintosh \& 
Quattrone, 2010). Previous studies also have the same concern by agreeing that asymmetric information has a positive effect towards budgetary slack (Ngo et al., 2017; Kren \& Maiga, 2015; Faria \& Silva, 2013; Aprila \& Hidayani, 2012; Damrongsukniwat et al., 2011; Fisher et al., 2002; Dunk, 1993).

\section{H1: Asymmetric information has a positive effect on budgetary slack}

\subsection{Participative Budgeting and Asymmetric Information}

One way that could be done to reduce asymmetric information is by using participative budgeting (Zonatto \& Lavarda, 2013). Participative budgeting can be interpreted as a budget preparation process, involving subordinates (Brink et al., 2018). This process begins with the presentation of general budget guidelines by top management and continues with the formulation of budget targets by managers who act as budget users (Noreen et al., 2014). According to Anthony \& Govindarajan (2007) participative budgeting can result in effective exchange of information and budget users could have a clearer understanding of their work through the interactions with superiors during the review and approval phases. The results of previous studies conducted by Kren \& Maiga (2015) found an empirical finding that participative budgeting could reduce the level of asymmetric information.

\section{H2: Participative Budgeting has a negative effect towards asymmetric information}

\subsection{Employee Motivation and Budgetary Slack}

Besides asymmetric information, another factor that could affect budgetary slack is the employee motivation (Baerdemaeker \& Bruggeman, 2015). Employee motivation in this study is more focused on intrinsic motivation, which is a desire that comes from within the employee to complete the job. These factors, namely pleasure, attraction, and feeling challenged to work positively without relying on external factors (McShane \& Glinow, 2018; Colquitt et al., 2017). Kinicki \& Fugate (2016) added that their research showed that intrinsic motivation is more durable and has a more positive impact on performance than extrinsic motivation. In other words, intrinsic motivation has a negative effect on budget slack. As in the theory of "self-determination", intrinsic motivation is known as autonomous motivation (Weibel et al., 2014). Moreover, Baerdermaeker \& Bruggeman (2015) have shown in their research that autonomous motivation is more capable to reduce the potential for slack the budget, compared to the use of controlled motivation (extrinsic motivation).

\section{H3: Employee Motivation has a negative effect towards Budgetary Slack}




\subsection{Participative Budgeting and Employee Motivation}

When employees are included in the budgeting planning process, their motivation will increase (Dow et al., 2015). The increased motivation the employees in achieving budget targets occurs because those employees who are invited to participate in the budget planning process have accepted these targets (Zimmerman, 2014; Shim, et al., 2012). There are many previous studies that analyze the effect of participative budgeting towards employee motivation. The results of these studies indicate that participative budgeting has a positive effect on employee motivation (Djalil et al., 2017; Yee et al., 2016; Dow et al., 2015).

\section{H4: Participative Budgeting has a positive effect towards Employee Motivation}

\section{METHODOLOGY}

This study used descriptive survey research design, with questionnaire, interviews and group discussions as data collection techniques. The questionnaire of this study was distributed via postal (mail survey), online survey and direct survey. In this study, the researchers included open- ended questions which are related to the research variables. It makes the researchers could explore several of other factors that might affect budgetary slack.

The population in this study was the heads of the responsibility center of SOE companies in Bandung, in a total of 27 companies. It is assumed that each SOE which became the population target had 50 heads of responsibility center. Thus, the respondents of this study were 1,350. The numbers of samples based on the population were determined based on the complexity of the model and the basic characteristics of the measurement model. According to Hair et al. (2014: 574), when the model contains five variables or less and in each variable, there are more than three measurable variables, it means that the minimum number of samples is 100. With this basis, the minimum sample that must be fulfilled is 100 respondents.

Respondents of this study were managers or heads of responsibilities centers. In terms of its relation to variable measurement, researchers measured the participative budgeting variables from the indicators which were adopted from Milani's study (1975). This is because the indicator developed by Milani (1975) is the most used indicator to measure participative budgeting. Then, asymmetric information variables were measured using indicators developed by Dunk (1993). This is because it is the most used indicator to measure asymmetric information. Meanwhile, employee motivation variables were measured using the indicators developed by Warr et al. (1979) that have been modified and linked to the budget by Dow et al. (2015) and have been widely used in previous studies. Meanwhile, budgetary slack variables were measured by indicators developed by Van der Stede (2000). This is because these indicators are the result of improvement from the indicators developed by Onsi (1973) and Dunk (1993). The indicators used 
were measured on a Likert scale (1-5). The data analysis technique used in this study was the LISREL structural equation model (SEM).

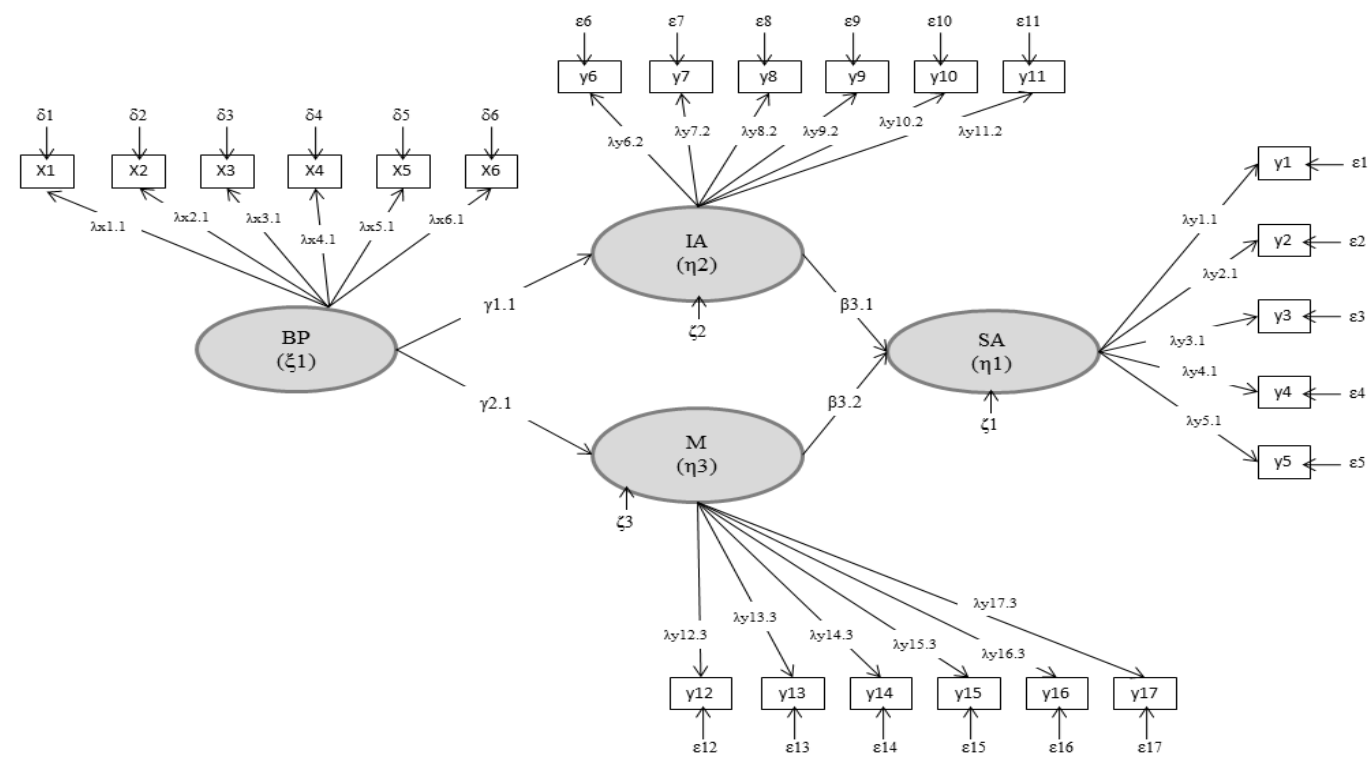

Figure 1. Theoretical Framework

Notes: $S A=$ Budgetary Slack; $I A=$ Asymmetric Information; $M=$ Motivation; $B P=$ Participative Budgeting

\section{RESULTS AND DISCUSSION}

\subsection{Data Normality Testing}

The data normality testing in the study were measured using the Lisrel 8.8 software with 229 samples collected. Based on the sample data, the results showed that the data did not meet the values of the multivariate normality assumption, so bootstrap data was conducted for approximately 1.5 times from the initial sample value. After bootstrapping the data, the number of samples became 350 data and the results of normality testing met the value of multivariate normality assumption ( $p$-value of skewness and kurtosis is $0.87>0.05$ ). Thus, the parameter estimation using Maximum Likelihood and data processing can be preceded to the next stage.

\subsection{Validity and Reliability of the Measurement Model Testing}

The tests was conducted by noticing at the value of standardized loading factor, construct reliability, and extracted variance in which the results are shown in the following table: 
Table 1. Validity and Reliability of the Measurement Model Testing

\begin{tabular}{|c|c|c|c|c|c|}
\hline \multirow{2}{*}{ Variables } & \multirow{2}{*}{$\begin{array}{l}\text { standardized } \\
\text { loading factor } \\
\geq 0,50\end{array}$} & \multirow{2}{*}{ Errors } & \multicolumn{2}{|c|}{ Reliabilities } & \multirow{2}{*}{ Notes } \\
\hline & & & $C R \geq 0,70$ & $V E \geq 0,50$ & \\
\hline SA & & & 0.86 & 0.56 & Good Reliability \\
\hline SA1 & 0.53 & 0.72 & & & Good Validity \\
\hline SA2 & 0.86 & 0.26 & & & Good Validity \\
\hline SA3 & 0.82 & 0.32 & & & Good Validity \\
\hline SA4 & 0.84 & 0.29 & & & Good Validity \\
\hline SA5 & 0.61 & 0.63 & & & Good Validity \\
\hline IA & & & 0.87 & 0.59 & Good Reliability \\
\hline IA1 & 0.55 & 0.70 & & & Good Validity \\
\hline IA2 & 0.55 & 0.70 & & & Good Validity \\
\hline IA3 & 0.77 & 0.41 & & & Good Validity \\
\hline IA5 & 0.91 & 0.17 & & & Good Validity \\
\hline IA6 & 0.96 & 0.08 & & & Good Validity \\
\hline M & & & 0.86 & 0.55 & Good Reliability \\
\hline M1 & 0.71 & 0.50 & & & Good Validity \\
\hline M3 & 0.63 & 0.61 & & & Good Validity \\
\hline M4 & 0.73 & 0.47 & & & Good Validity \\
\hline M5 & 0.80 & 0.36 & & & Good Validity \\
\hline M6 & 0.84 & 0.29 & & & Good Validity \\
\hline $\mathrm{BP}$ & & & 0.81 & 0.60 & Good Reliability \\
\hline BP1 & 0.63 & 0.61 & & & Good Validity \\
\hline BP3 & 0.82 & 0.33 & & & Good Validity \\
\hline BP6 & 0.85 & 0.27 & & & Good Validity \\
\hline
\end{tabular}

Sources: processed by researchers

Based on the above results, it can be seen that the IA4, M2, BP2, BP4, and BP5 indicators have been removed because they are invalid. 


\subsection{Goodness of Fit Testing}

The test results of the goodness of fit are shown in the following table 4 using the criteria stated by Riadi (2018: 113-115) and Wijanto (2008: 61-62).

Table 2. Goodness of Fit Test

\begin{tabular}{|c|c|c|c|}
\hline GOF size & $\begin{array}{l}\text { Estimation } \\
\text { Result }\end{array}$ & Criteria & Result \\
\hline RMSEA & 0.06 & $\begin{array}{l}\text { RMSEA } 0.05 \\
\text { RMSEA } \leq 0.08\end{array}$ & Good Fit \\
\hline NFI & 0.95 & $\mathrm{NFI} \geq 0.90$ & Good Fit \\
\hline TLI atau NNFI & 0.97 & $\mathrm{TLI} \geq 0.90$ & Good Fit \\
\hline CFI & 0.97 & $\mathrm{CFI} \geq 0.97$ & Good Fit \\
\hline IFI & 0.97 & $\mathrm{IFI} \geq 0.90$ & Good Fit \\
\hline RFI & 0.94 & $\mathrm{RFI} \geq 0.90$ & Good Fit \\
\hline $\mathrm{CN}$ & 206.58 & $\mathrm{CN}>200$ & Good Fit \\
\hline SRMR & 0.06 & $\begin{array}{l}\text { SRMR } \leq 0.05 \\
0.05<\text { SRMR }<0.10\end{array}$ & Marginal Fit \\
\hline GFI & 0.92 & $\mathrm{GFI} \geq 0.90$ & Good Fit \\
\hline AGFI & 0.89 & $\begin{array}{l}A G F I \geq 0.90 \\
0.80 \leq A G F I<0.90\end{array}$ & Marginal Fit \\
\hline
\end{tabular}

Sources: processed by researchers

Based on the results above, the research model can be stated as "Fit" because the majority of the results indicated "Good Fit".

\subsection{Hypothesis Testing and Discussion}

Hypothesis testing is conducted using the Lisrel 8.8 software after the model is stated as fit and it is shown in table 5 below:

Table 3. Hypothesis Test Results

\begin{tabular}{|c|c|c|c|c|c|c|}
\hline Hypothesis & Path & $\begin{array}{c}\text { Path } \\
\text { Coef. }\end{array}$ & Error & $\begin{array}{c}\text { T- } \\
\text { Value }\end{array}$ & $\mathbf{R}^{2}$ & Results \\
\hline $\mathrm{H} 1(+)$ & $\mathrm{IA} \rightarrow \mathrm{SA}$ & 0.27 & 0.065 & 4.12 & 0.26 & Accepted \\
\hline $\mathrm{H} 2(-)$ & $\mathrm{BP} \rightarrow \mathrm{IA}$ & 0.22 & 0.057 & 3.84 & $\begin{array}{c}0.04 \\
8\end{array}$ & Rejected \\
\hline $\mathrm{H} 3(-)$ & $\mathrm{M} \rightarrow \mathrm{SA}$ & -0.88 & 0.14 & -6.19 & 0.26 & Accepted \\
\hline $\mathrm{H} 4(+)$ & $\mathrm{BP} \rightarrow \mathrm{M}$ & 0.50 & 0.063 & 7.89 & 0.25 & Accepted \\
\hline
\end{tabular}

Sources: processed by researchers 


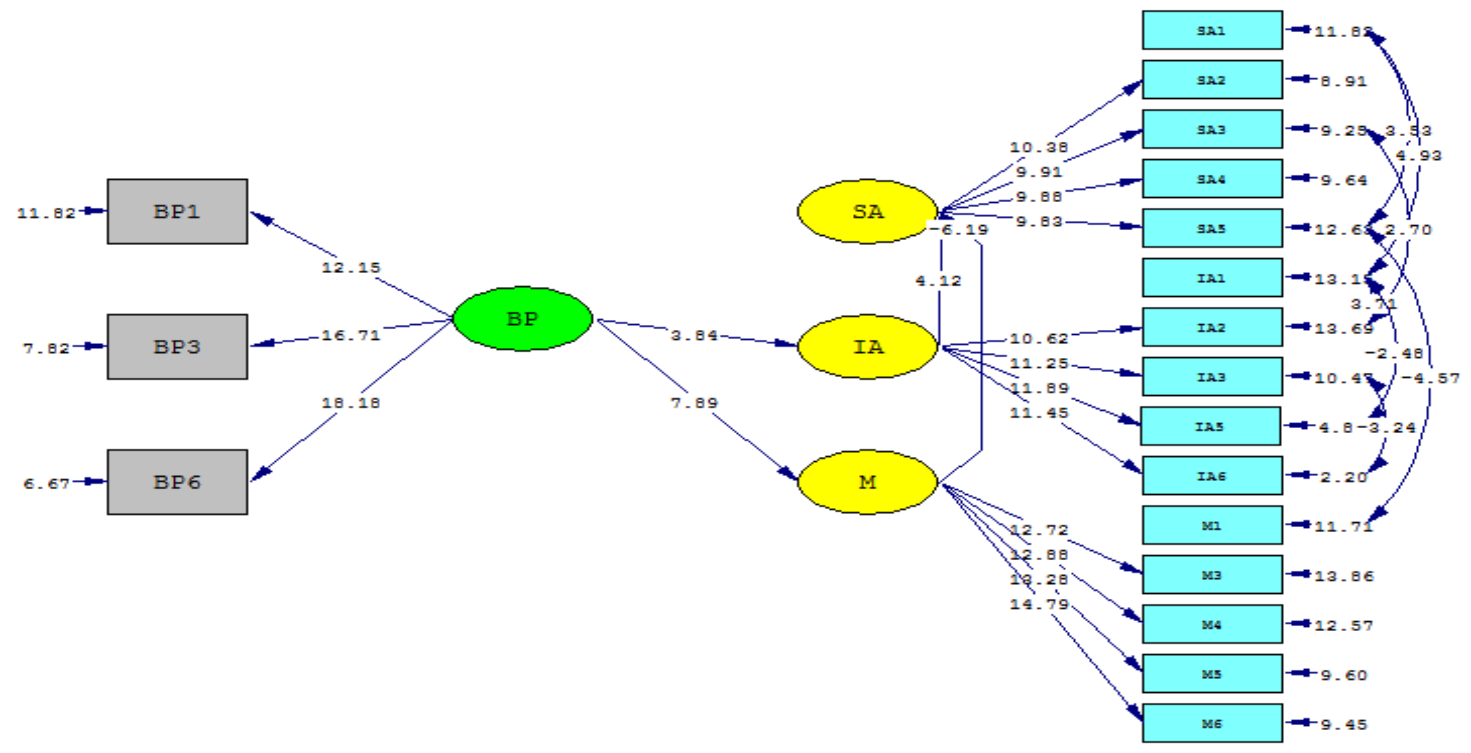

Figure 2. Structural Model Analysis (t-value) with Lisrel 8.8

\section{a. Asymmetric information has a positive effect on budgetary slack (H1)}

The coefficient of the effect of asymmetric information towards budgetary slack is 0.27 with an error value of 0.065 , resulting in a t value of 4.12 . Because the hypothesis stated a positive effect, then the right-direction test was conducted ( $t$ statistic $>$ t-table $=4.12>1.96$ ). Based on these results, it can be concluded that the effect of asymmetric information towards budgetary slack is significant and the first hypothesis can be accepted. This condition shows that the high asymmetric information can cause a budgetary slack on SOE in Bandung. The major cause of the high asymmetric information is the complexity of the procedures in preparing, revising and implementing budget activities, which are often indicated to only complicated budgeters. One example of the complexity of the procedure that occurs in SOE in Bandung is the existence of a review process that is conducted several times and in each review it causes budget cuts. These difficulties often make the budgeting participants to mark-up / mark down the budget made in order to create a bumper in the implementation of the budget. This behavior creates a perception that marking-up / marking down is a common thing to do. This is in line with the results of research conducted by Ngo et al. (2017), Kren \& Maiga (2015), Faria \& Silva (2013), Aprila \& Hidayani (2012), Damrongsukniwat et al. (2011), Fisher et al. (2002), and Dunk (1993) who acknowledge that asymmetric information has a positive effect towards the occurrence of budgetary slack. 


\section{b. Participative budgeting has a negative effect towards asymmetric information ( $\mathrm{H} 2)$}

The coefficient of the effect of participative budgeting towards asymmetric information is 0.22 with an error value of 0.057 , resulting in a t value of 3.84 . As the hypothesis stated a negative effect, a left-direction test was conducted (t-statistic <$\mathrm{t}$-table). The results showed that the t-statistic value is more than the negative ttable value (3.84>-1.96). Thus, it can be concluded that the direct effect of participative budgeting towards asymmetric information is not significant and the second hypothesis cannot be accepted. On the results of respondents' observations and interviews, asymmetric information has encouraged SOEs in Bandung to make a policy that involves lower-level managers to participate in budgeting. Involving managers in budgeting is one of the form of participation that is expected to be able to create information related to the responsibilities of the lower-level managers to be extracted, shared and considered in budgeting. However, in reality, this policy does not make information exchange becomes more effective. This happens because the majority of respondents assume that budgeting participation is only a procedure that must be passed without considering the benefits of such involvement. This is also supported by the distribution of respondents' data showing that the majority of working ages in companies are more than 5 years. These respondents have the perception that the lower level managers are the most familiar with the technical work they do because they have had a working age of more than 5 years in the company. It is through this perception that lower-level managers use budgeting participation as a facility to negotiate in lowering budget targets. This finding is not in line with the results of Kren \& Maiga's research (2015). However, it is in line with the results of research conducted by Basuki (2015), Cheng et al. (2014), Lavarda \& Almeida (2013), and Douglas \& Wier (2000) which stated that companies with participative budgeting are not able to minimize the occurrence of asymmetric information.

\section{c. Employee motivation has a negative effect on budgetary slack $(\mathrm{H} 3)$}

The coefficient of the effect of employee motivation towards budgetary slack is -0.88 with an error value of 0.14 , resulting in a value of -6.19 . Because the hypothesis stated a negative effect, the left-direction test was conducted (tstatistics <-t-table $=-6.19<-1.96$ ). Next, it can be concluded that the direct effect of employee motivation towards budgetary slack is significant and the third hypothesis can be accepted. The condition that occurs in SOE in Bandung indicates a high employee motivation. High motivation is created due to the basis of measuring the performance of individuals and responsibilities units of SOEs in Bandung based on achieving the results of working targets which have been agreed in the budget. In the end, the lower-level managers who are motivated to get a good appraisal indirectly will try to minimize the occurrence of budgetary slack. This finding is in line with the results of research conducted by Baedermaeker \& Bruggeman (2015). 


\section{d. Participative budgeting has a positive effect towards employee motivation (H4)}

The coefficient of the effect of participative budgeting towards employee motivation is 0.50 with an error value of 0.063 , resulting in a t value of 7.89 . As the hypothesis showed a positive effect, the right-direction test was conducted (tstatistic $>$ t-table $=7.89>1.96)$. It can be concluded that the direct effect of participative budgeting towards employee motivation is significant and the fourth hypothesis can be accepted. Participative budgeting has made lower-level managers in SOEs in Bandung become more motivated in carrying out their duties and responsibilities. With the invitation to participate, lower-level managers feel being valued and recognized for their existence. When an employee feels valued and recognized of his/her existence, then the desire of employees to actualize themselves increases. The same result is also found in research conducted by Djalil et al. (2017), Yee et al. (2016), and Dow et al. (2015). They affirm that participation in budgeting affects the employee motivation in acceptance and commitment for the budget goals.

\section{CONCLUSION}

Based on the results of data testing and discussion for each hypothesis, it can be concluded that:

a. Asymmetric information has a positive effect towards budgetary slack,

b. Participative budgeting has a positive effect towards asymmetric information,

c. Employee motivation has a negative effect towards budgetary slack,

d. Participative budgeting has a positive effect towards employee motivation.

The suggestion that can be given by researchers to the Ministry of SOEs is that teamwork within SOEs needs to be built very carefully. The teamwork built does not only require professionalism at work, but there should be an intimacy and comfort created at work. Leaders should be able to position themselves both when to act decisively and when to embrace their employees. Thus, employees will not feel reluctant and will be more open in sharing information and difficulties encountered in the work, even become motivated to provide the best results in every job. The existence of periodic reports related to detailed field conditions and achieving daily targets is also important to be implemented within the company and known by the leaders. This will help to give leaders a better understanding of the conditions faced by employees, so asymmetric information and slack activities can be minimized. Meanwhile, training and refreshment of corporate's values and spirit becomes an important thing so that employees are more motivated to uphold the 
corporate values and spirit. Increment of employee awareness of corporate values and spirit will make these employees achieve the company goals by minimizing slack activities.

The research was conducted only limited in SOEs in Bandung with a total sample of 229 respondents. By this limitation, it is expected that future researchers can develop more by expanding the area of research and collecting more samples, so that research results will be closer to the condition that occurs in the population.

\section{ACKNOWLEDGEMENT}

This research could not have proceeded without the funding from the Ministry of Research, Technology and Higher Education Republic of Indonesia. Therefore, we as the researchers would like to thank you profusely for the help of funding so that our research can run smoothly.

\section{REFERENCE}

Adnan, N.L., \& Ali, R. 2014. How Prevalent is Dysfunctional PMS Behaviour among Malaysian Bankers? Journal of Applied Environmental and Biological Sciences, 4(6S), 41-49.

Alamsyah, W. 2018. ICW: Korupsi Pengadaan Barang 2017 Meningkat, Negara Rugi Rp 1T. Retrieved July 9, 2018, from detiknews: https://news.detik.com/berita/d-3885311/icw-korupsi-pengadaan-barang2017-meningkat-negara-rugi-rp-1-t

Anthony, R.N., \& Govindarajan, V. 2007. Management Control Systems. Singapore: McGraw-Hill Education (Asia).

Aprila, S., \& Hidayani, S. 2012. The Effect of Budgetary Participation, Asymmetry Information, Budget Emphasis and Comitment Organization to Budgetary Slack at SKPD Governmental of Bengkulu City. The 13th Malaysia Infonesia Conference on Economics, Management and Accounting. Malaysia: MICEMA.

Baerdemaeker, J.D., \& Bruggeman, W. 2015. The Impact of Participation Strategic Planning on Managers' Creation of Budgetary Slack: The Mediating Role of Autonomous Motivation and Affective Organizational Commitment. Management Accounting Research, xxx-xxx.

Barki, H., \& Hartwick, J. 1989. Rethinking the Concept of User Involvement. MIS Quaterly, 13(1), 53-63. 
Basuki, F.H. 2015. Participatory Budgeting and Managerial Performance in Conditions of Information Asymmetry. IJABER, 13(6), 4529-4555.

Brink, A.G., Coats, J.G., \& Rankin, F.W. 2018. Who's the boss? The economic and behavioral implications of various characterizations of the superior in participative budgeting research. Journal of Accounting Literature, 89-105.

Chandra, D.S. 2011. Management Control Systems: Principles and Practices (Eastern Economy ed.). New-Delhi: PHI Learning Private Limited.

Cheng, K.-C., Chen, T.-C., \& Shih, N.-S. 2014. The Influence of Budgetary Participation by R\&D Managers on Product Innovation Performances: The Effect of Trust, Job Satisfaction and Information Asymmetry. Asia Pacific Management Review, 19(2), 133-150.

Colquitt, J.A., LePine, J.A., \& Wesson, M.J. 2017. Organizational Behavior: Improving Performance and Commitment in The Workplace (5th ed.). New York: McGraw-Hill Education.

Damrongsukniwat, P., Kunpanitchakit, D., \& Durongwatana, S. 2011. The Measurement and Determinats of Budgetary Slack: Empirical Evidence of Listed Companies in Thailand. Thailand: Chulalongkorn University.

Dermer, J. 1975. The Interrelationship of Intrinsic and Extrinsic Motivation. The Academy of Management Journal, 18(1), 125-129.

Djalil, M.A., Indriani, M., \& Muttaqin. 2017. The Influence of Organizational Commitment and Motivation in the relationship between Budget Participation and Managerial Performance (Empirical Study on Provincial Government Agencies (SKPA) of Aceh Province, Indonesia). Broad Research in Accounting Negotiation, and Distribution (BRAND), 8(1), 12-24.

Douglas, P.C., \& Wier, B. 2000. Integrating Ethical Dimencions into a Model of Budgetary Slack Creation. Journal of Business Ethics, 28(3), 267-277.

Dow, K.E., Watson, M.W., Greenberg, P. S., \& Greenberg, R. H. 2015. Understanding Participation: Situational Participation, Intrinsic Involvement, and Influences. Advances in Management Accounting, 21, 25-47.

Drury, C. 2018. Management and Cost Accounting (10th ed.). Hampshire: Cengage Learning EMEA.

Dunk, A.S. 1993. The Effect of Budget Emphasis and Information Asymmetry on The relation Between Budgetary Participation and Slack. The Accounting Review, 68(2), 400-410. 
Dunk, A.S., \& Nouri, H. 1998. Antecedents of Budgetary Slack: A Literature Review and Synthesis. Journal of Accounting Literature, 17, 72-96.

Fall, A., \& Roussel, P. 2014. Compensation and Work Motivation: SelfDetermintation Theory and the Paradigm of Motivation through Incentives. In M. Gagne, The Oxford Handbook of Work Engagement, Motivation, and Self-Determination Theory (pp. 199-217). New York: Oxford University Press.

Fanani, Z., \& Saudale, G.E. 2018. Influence of Information Asymmetry and SelfEfficacy on Budgetary Slack: An Experimental Study. Jurnal Akuntansi dan Keuangan, 20(2), 62-72.

Faria, J.A., \& Silva, S.M. 2013. The Effect of Information Asymmetry on Budget Slack: An Experimental Research. African Journal of Business Management, 7(13), 1086-1099.

Fisher, J.G., Maines, L.A., Preffer, S.A., \& Sprinkle, G.B. 2002. Using Budgets for Performance Evaluation: Effect of Resources Alocation ang Horizontal Information Asymmetry on Budget Proposals, Budget Slack and Performance. The Accounting review, 77(4), 847-865.

Goebel, S., \& WeiBenberger, B.E. 2016. The Dark Side of Tight Financial Control: Causes and Remedies of Dysfunctional Employee Behaviors. Schmalenbach Business Review, 17, 69-101.

Greenberg, J. 2011. Behavior in Organizations (10th ed.). Harlow: Pearson Education Limited.

Hair, J.F., Black, W.C., Babin, B.J., \& Anderson, R.E. 2014. Multivariate Data Analysis (7th ed.). Harlow: Pearson Education Limited.

Hansen, D. R., Mowen, M. M., \& Guan, L. 2009. Cost Management: Accounting \& Control (6th ed.). USA: South-Western Cengage Learning.

Horngren, C.T., Datar, S.M., \& Rajan, M.V. 2015. Cost Accounting: A Managerial Emphasis (15th ed.). USA: Pearson Education.

Jaworski, B.J., \& Young, S.M. 1992. Dysfunctional Behavior and Management Control an Empirical Study of Marketing Managers. Accounting Organizations and Society, 17(1), 17-35.

Kinicki, A., \& Fugate, M. 2016. Organizational Behavior: A Practical, ProblemSolving Approach. New York: McGraw-Hill Education. 
Kren, L., \& Maiga, A. 2015. The Intervening Effect of Information Asymmetry on Budget Participation and Segment Slack. Advances in Management Accounting, 141-157.

Kridawan, A., \& Mahmud, A. 2014. Pengaruh Kejelasan Sasaran Anggaran terhadap Senjangan Anggaran dengan Asimetri Informasi sebagai Variabel Moderasi. Accounting Analysis Journal, 3(1), 361-369.

Lavarda, C.E., \& Almeida, D. M. 2013. Budget Participation Informational Asymmetry: A Study in a Multinational Company. Brazilian Business Review, 10(2), 72-94.

Macintosh, N., \& Quattrone, P. 2010. Management Accounting and Control Systems: An Organizational and Sociological Approach. United Kingdom: John Wiley \& Sons Ltd.

McShane, S.L., \& Glinow, M. A. 2018. Organizational Behavior: Emerging Knowledge, Global Reality (8th ed.). New York: McGraw-Hill Education.

Merchant, K. A. 1981. The Design of the Corporate Budgeting System: Influences on Managerial Behavior and Performance. The Accounting Review, 56(4), 813-829.

Merchant, K.A., \& Van der Stede, W. A. 2012. Management Control Systems: Performance Measurement, Evaluation, and Incentives (3rd ed.). Harlow: Financial Times/Prentice Hall.

Milani, K. 1975. The relationship of Participation in Budget Setting to Industrial Supervisor Performance and Attitudes: A Field Study. The Accounting Review, 50(2), 274-284.

Newstrom, J.W. 2015. Organizational Behavior: Human Behavior at Work (14th ed.). Singapore: McGraw-Hill Education.

Ngo, Q.-H., Doan, T.-N.-N., \& Huynh, T.-N. 2017. A Study on Managers' Creation of Budgetary Slack in Emerging Economies: The Case of Vietnam. Asian Journal of Accounting Research, 2(2), 15-28.

Noreen, E.W., Brewer, P. C., \& Garrison, R. H. 2014. Managerial Accounting for Managers (3rd ed.). New York: McGraw-Hill//rwin.

Novo, L. 2017. Suka Duka Whistleblower. Retrieved July 9, 2018, from Metro TV News: http://telusur.metrotvnews.com/news-telusur/yNLeryWb-suka-dukawhistleblower

Onsi, M. 1973. Factor Analysis of Behavioral Variables Affecting Budgetary Slack. The Accounting Review, 48(3), 535-548. 
Pangarso, B.S. 2018. Pimpinan Komisi VI DPR Desak Dirut Waskita Mundur. Retrieved July 9, 2018, from Teropong Senayan: http://www.teropongsenayan.com/82552-pimpinan-komisi-vi-dpr-desakdirut-waskita-mundur

Parmoredjo, E.Y. 2018. Kebijakan Pemotongan Anggaran di PT Telekomunikasi Indonesia, Tbk. (M. L. Kenisah, Interviewer)

Riadi, E. 2018. Statistik SEM Structural Equation Modeling dengan LISREL. Yogyakarta: CV Andi Offset.

Rum, M. 2017. Kejaksaan Perluas Pengusutan Kasus Korupsi Handling BBM Fiktif di Pertamina. Retrieved July 9, 2018, from Gres News: http://www.gresnews.com/berita/hukum/113178-kejaksaan-perluaspengusutan-kasus-korupsi-handling-bbm-fiktif-di-pertamina/

Samad, A. 2018. Ini Dia Lima Penyakit Birokrasi Menurut Abraham Samad. Retrieved July 9, 2018, from Harian Jogja: http://news.harianjogja.com/read/2018/04/08/500/908775/ini-dia-limapenyakit-birokrasi-menurut-abraham-samad

Shim, J.K., Siegel, J.G., \& Shim, A.I. 2012. Budgeting Basics and Beyond (4th ed.). USA: John Wiley \& Sons, Inc.

Syarif, L.M. 2018. Nindya Karya Jadi Tersangka KPK, Ini Tanggapan Pemerintah. Retrieved July 9, 2018, from iNews: http://www.inews.id/finance/read/92393/nindya-karya-jadi-tersangka-kpk-initanggapan-pemerintah?sub_slug=bisnis

Van der Stede, W.A. 2000. The Relationship between Two Consequences of Budgetary Controls: Budgetary Slack Creation and Managerial Short-Term Orientation. Accounting Organizations and Society, 25, 609-622.

Walther, L.M., \& Skousen, C.J. 2009. Budgeting and Decision Making. BookBoon.

Warr, P., Cook, J., \& Wall, T. 1979. Scales for the Measurement of Some Work Attitudes and Aspects of Psychological Well-Being. Journal of Occupational Psychology, 52, 129-148.

Weibel, A., Wiemann, M., \& Osterloh, M. 2014. A Behavioral Economics Perspective on the Overjustification Effect: Crowding-In and Crowding-Out of Intrinsic Motivation. In M. Gagne, The Oxford Handbook of Work Engagement, Motivation, and Self-Determination Theory (pp. 72-84). NewYork: Oxford University Press. 
Weygandt, J.J., Kimmel, P.D., \& Kieso, D.E. 2015. Managerial Accounting: Tools for Business Decision Making (7th ed.). Singapore: John Wiley \& Sons Singapore Pte. Ltd.

Wijanto, S.H. 2008. Structural Equation Modeling dengan Lisrel 8.8: Konsep \& Tutorial. Yogyakarta: Graha IImu.

Yee, C.M., Khin, E.W., \& Ismail, K. 2016. An Analysis of Budgetary Goals Impacting Organizational Performance. Audit Financiar, XIV(5 (137)), 551563.

Zimmerman, J.L. 2014. Accounting for Decision Making and Control. United States of America: McGraw-Hill Education.

Zonatto, V.C., \& Lavarda, C.E. 2013. Evidence of the effects of budget participation on information asymmetry, occupational stress and work performance. Advances in Scientific and Applied Accounting, 6(11), 92-111. 